\title{
TOXICOLOGICAL STUDIES ON THE STATUS OF COTTON LEAF WORM SPODOPTERA LITTORALIS (BOISD) RESISTANCE TO CERTAIN INSECTICIDES IN MENOUFIA GOVERNORATE
}

\author{
M. A.A. Sayed-Ahmed ${ }^{(1)}$, Zeinab A. El-Bermawy ${ }^{(1)}$ and T.A. El-Shiekh ${ }^{(2)}$ \\ (1) Department of Pesticides, Fac. Agriculture, Menoufia Univers . \\ (2) Plant protection Res. Inst. Dokki, Giza .
}

Received: Jan. 9, 2019

Accepted: Jan. 22,2019

\begin{abstract}
The response of cotton leaf worm $4^{\text {th }}$ instar larvae, representing field population of Menoufia governorate to different insecticide groups (organophosphatescarbamates- synthetic pyrethroids- insect growth regulators and naturally- derived insecticides "Naturalyte") were determined and expressed as $L C_{50}$ values. The comparison between investigated compounds was made on the basis of tolerance or resistance ratio. Data illustrated that, the highest tolerance ratio was recorded for synthetic pyrethroids followed by carbamates, then organophosphates. In general the population exhibited moderate level of tolerance to the unconventional insecticides including insect growth regulators and naturalytes.
\end{abstract}

The $4^{\text {th }}$ instar larvae of S.littoralis were subjected to selection with chlorpyrifos and Spinenotram for 6 successive generations .

Key words: Cotton leafworm- tolerance- organophosphate- carbamates- synthetic pyrethroids- IGRs- Naturalyte.

\section{INTRODUCTION}

Resistance to commonly used insecticides is widespread. (Georghiou 1983) and continued use of conventional insecticides is likely to intensify selection for resistance in the field. Resistance is expressed in terms of the ratio of $L C_{50}$ or $L C_{50}$ of the resistant strain compared with susceptible strain. Alternatively, an approach called the discriminating or diagnostic dose test was used were one dose is often investigated and the mortality of the susceptible test strains are compared.

Therefore, in order to explore strategies for resistance management, if possible before any resistance is manifested in field populations, the present experimental trials reported here were designed to study the phenomenon of resistance in the cotton leaf worm from different point of view namely:

1. Insect rearing under laboratory conditions for susceptible strain and colony from different field strain collected from cotton and vegetable crops of Menofia governorate.

2. Bioassay of traditional insecticide/group

(organophosphorous, carbamate, Pyrethroid and IGR's ) and three novel insecticides with unique made of action and determination of resistance level for these insecticides in the experimental population .

3. Selection for several generations (6) of a field population to one traditional insecticide compared with one novel insecticide and determination of resistance status.

\section{MATERIALS AND METHODS}

I-Insecticides used:

Commercial formulations of the following insecticides, representing different groups, were used in the bioassay experiments : 
1-Orgenophosphates:

Chlorpyrifos $48 \%$ EC.

Trade Name: Dursban

Profenfos : $72 \%$ EC.

Trade Name: Sylian

2- Carbamates :

Methomyl : 90\% SP

Trade Name: Lannate

3- Synthetic pyrethroids:

Esfenvalerate: $20 \%$ EC

Trade Name: Sumi-alpha

Deltamethrin: $2.5 \%$ EC

Trade Name: Decis

4- Insect growth regulators:

Flufenoxuron: 10\% DC

Trade Name: Floxate

Hexaflumuron : 10\% EC

Trade Name: Dimecron

Methoxyfenozide: 24\% FL

Trade Name: Runnar

5- Naturally-derived insecticides

"Naturalyte":

Spinetoram: $12 \%$ SC

Trade Name: Radiant

Pyridalyl : 50\% EC

Trade Name: Pleo

Indoxacarb: 15\% EC

Trade Name: Avant

\section{II: Insect strain:}

\section{1-Suscetptible strain:}

The strain has been reared in the laboratory for more than two years was kindly supplied from the central laboratory of pesticides, Dokki, Giza .

\section{Field strain :}

Egg masses of cotton leafworm were collected from the cotton fields of several (three) representing locations of Menofia governorate, during growing season of 2016.

\section{Resistant Strains :}

To obtain strain specifically resistant to the conventional groups, the field strain of Menoufia governorate was firstly bio assayed for eight conventional insecticides representing four main groups, i.e, Chlorpyrifos and Profenfos
(Organophosphates), Methomyl

(Carbamates), Esfenvalerate and Deltamethrin (Pyrethroids), and Hexaflumuron, Flufenoxuron and Methoxyfenozide ( IGRS ).

Secondly, a total number of $\mathbf{4 0 0 0}$ fourth instar larvae of S.littoralis was divided into eight sub colony, each sub colony was selected to one of the premonition conventional insecticides. The same work was done for three unconventional insecticides, i.e., Spinetoram, Pyridalyl and Indoxacarb. The tolerance or / and resistant strains have been reared under the experimental insecticidal pressure are :

1-Chlorpyrifos tolerant strain .

2- Spinetoram tolerant strain.

The orgin of these tolerant strains was egg masses collected from the fields of Menoufia - governorate and kept in the rearing room under insecticidal pressure for 6 successive generations to Chlorpyrifos and Spinetoram

Both strains were reared in the laboratory as described by El-Defrawi et al. (1964) under constant laboratory conditions of $25^{\circ} \mathrm{C} \pm 1$, and $70 \% \pm 5 \mathrm{RH}$. Under these conditions the larvae reared till $4^{\text {th }}$ instar on the $6^{\text {th }}-8^{\text {th }}$ days after hatching.

\section{Buildup of resistance :}

On a trial to build up tolerant or resistant strains of cotton leafworm to one recommended insecticide Chlorpyrifos, in addition to new candidate insecticide of microorganism origin Spinetoram .The following technique had been adopted .The susceptibility of the insecticide used in selection was assayed at the level of $\mathrm{LC}_{50}$ at each generation.

The LC $_{50}$ concentration of each insecticide was used as pressure dose for treating different successive 
generations. The limit $\mathrm{LC}_{30}$ was chosen to protect the population from stronger pressure and maintain the strains as long as possible. The selection was maintained by use leaf dipping technique on 3000 larvae $\left(4^{\text {th }}\right.$ instar). Twenty four hour after treatment, the survivors were collected and transferred to clean jars containing fresh caster bean leaves and were reared as mentioned before. This was the parents. The same technique of selection and rearing was followed on every successive generation until $6^{\text {th }}$ generation of the Chlorpyrifos and Spinetoram.

The mortality curve of each material was obtained by five to seven concentrations using 30 larvae for each concentration, distributed in three jars (replicates). The data was corrected using Abbott's Formula (Abbott, 1925). Dosage mortality regression line were plotted out according to Finney (1952), to estimate $\mathrm{LC}_{30}, \mathrm{LC}_{50}$ and $\mathrm{LC}_{95}$ values and their slopes.

The tolerance ratio (T.R.) of investigated insecticides were estimated according to the following equation:

Tolerance Ratio $=\frac{}{\text { LC }_{50} \text { of laboratory strain }}$

\section{RESULTS AND DISCUSSION}

1- Susceptibility spectrum investigated pesticides:

The response of Menofia field strain to various insecticides groups: organophosphates, carbamates, synthetic pyrethroids, inset growth regulators (IGRs) and naturally-derived compounds are shown in Table 1 and 2 .

A- As for conventional insecticides, and based on $L^{2} C_{50}$ values, after $24 \mathrm{~h}$ from treatment, it is obvious that (Table 1): Esfenvalerate was the most effective (160.77 ppm) followed by Deltamethrin (291.71ppm ) . As for tolerance ratio, vigor tolerance was recorded for Deltamethrin (13.65 fold) and Esfenvalerate (12.68 fold ).

The $\mathbf{L C}_{50}$ values of organophosphrous group, indicated that chlorpyrifos was the most effective $(80.05 \mathrm{ppm})$ followed by profenofos (107.29 $\mathrm{ppm})$. As for tolerance spectrum high level of tolerance ratios was detected to profenofos (7.24 fold), while, tolerance ratio of chlorpyrifos recorded (5.21 fold). Regarding the carbamates group, the LC $_{50}$ values recorded (153.37 ppm) .As for tolerance ratio, high level of tolerance was recorded ( 8.23 fold).

Table (1): Response of Menoufia field strain of S.littoralis, $4^{\text {th }}$ instar larvae to various conventional insecticides after $24 \mathrm{hr}$ from treatment.

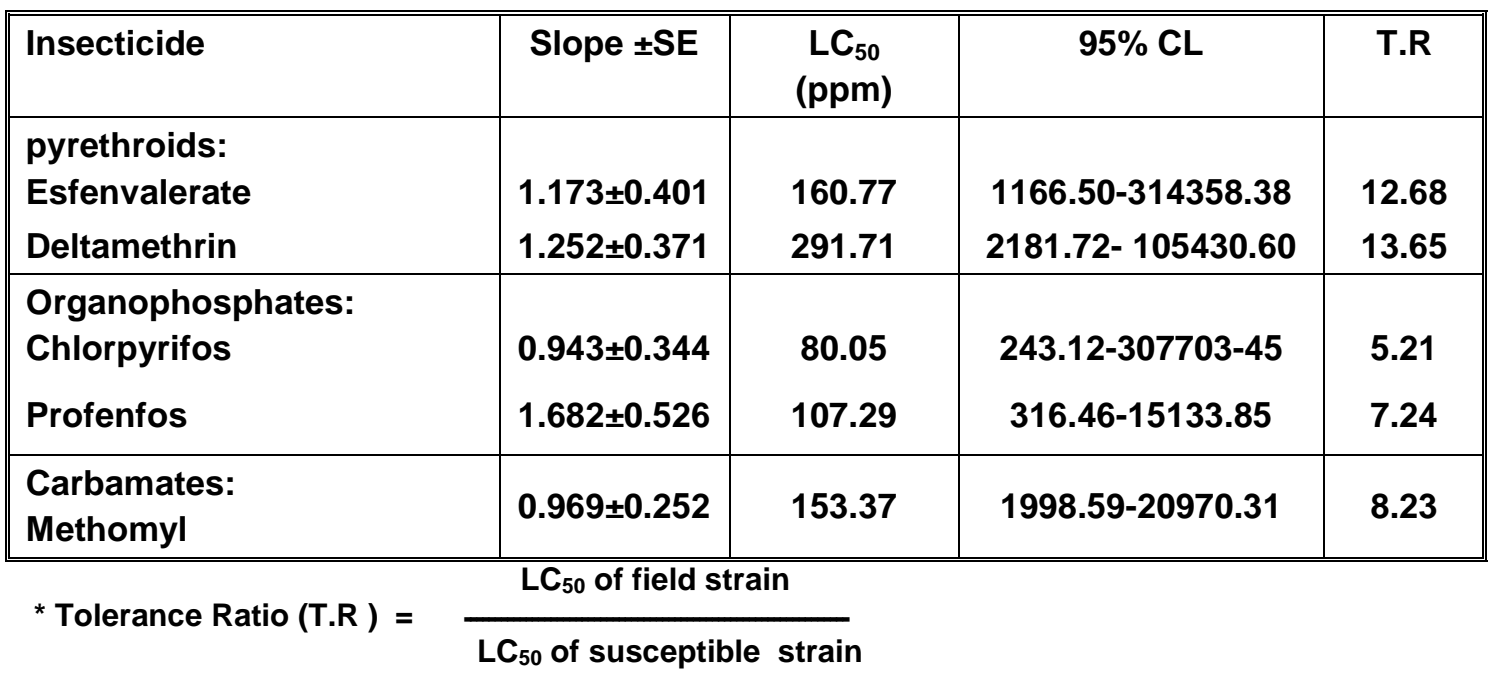


M. A.A. Sayed-Ahme, et al.,

Table (2): Response of Menoufia Field strain of S.littoralis, $4^{\text {th }}$ instar larvae to various unconventional insecticides after $48 \mathrm{hr}$ from treatment.

\begin{tabular}{|l||c||c||c||c||}
\hline Insecticide & Slope \pm SE & $\begin{array}{c}\text { LC } \\
(\mathrm{ppm})\end{array}$ & $95 \% \mathrm{CL}$ & $\mathrm{T} . \mathrm{R}$ \\
\hline \hline $\begin{array}{l}\text { Insect growth regulators: } \\
\text { Hexaflumuron }\end{array}$ & $1.992 \pm 0.634$ & 81.05 & $270.32-4827.80$ & 6.57 \\
$\begin{array}{l}\text { Flufenoxuron } \\
\text { Methoxyfenozide }\end{array}$ & $1.164 \pm 0.430$ & 62.11 & $430.67-32882.5$ & 10.09 \\
\hline $\begin{array}{l}\text { Naturally-derived products } \\
\text { (naturalyte): }\end{array}$ & $1.128 \pm 0.429$ & 60.26 & $440.17-602311.93$ & 5.03 \\
$\begin{array}{l}\text { Spinetoram } \\
\text { Pyridayl }\end{array}$ & $1.431 \pm 0.488$ & 80.60 & $405.75-42091.09$ & 5.64 \\
Indoxacarb & $1.299 \pm 0.437$ & 69.28 & $402.56-67402.77$ & 6.61 \\
\hline
\end{tabular}

* Tolerance Ratio (T.R) $=\frac{\text { LC }_{50} \text { of field strain }}{\text { LC }_{50} \text { of susceptible strain }}$

B- Data of unconventional insecticides was tabulated in Table (2). As for tested insect growth regulators (IGRs) the $L C_{50}$ values of 48 hours after treatment, revealed that Methoxyfenozide was more effective (60.26 ppm) followed by Flufenoxuron (62.11 ppm), whereas Hexaflumuron (81.05 ppm) was the least in this respect. However, moderate levels of tolerance ratios were detected to Methoxyfenozide (5.03 fold) and Hexafluumuron (6.57 fold), whereas Flufenoxuron (10.09 fold) recorded vigor tolerance in this respect .

In case of naturally-derived compounds data revealed that Pyridalyl (69.28 ppm) was more effective than Spinetoram (80.6 ppm) and Indoxacarb (88.22 ppm). Regarding the tolerance ratio, no considerable differences were found between Spinetoram (5.64 fold) and (5.98 fold), and both were less effective than Pyridalyl (6.61 fold).

Summarizing the screening of resistance spectrum of the prementioned results,for each investigated pesticide demonstrate, in general different patterns of changes in tolerance rate and/or buildup of resistance of the cotton leafworm in Menofia Governorate. Kinpling (1950) defined resistance as a 5 to 10-fold increase in the $L_{50}$ and/or LC $_{50}$ values.

The mean tolerance ratio (Tables 3,4 ) showed that Deltamethrin was the highest insecticide to which resistance phenomenon was exhibited where resistance ratio reached $\mathbf{1 3 . 6 5}$ fold. In previous studies by El-Bermawy et al. (1991) recorded the same result, they found high resistance level for Deltamethrin ( $R R=925$ fold) in five governorates representing lower Egypt. Such reversion of resistance to pyrethroids after 27 years of use could be due to the type or/and the sequence of compounds used in chemical control program during successive seasons in Menoufia governorate. Rashwan et al. (1991) suggested that the change in tolerance rates resulting in enhancement of resistance in some Governorate and high sensitivity in others, can be explained in terms of (1) the previous history of insecticides was in those specific Governorates and (2) the type and sequence of insecticides used during the same season. On the other hand, in an early study. El-Guindy et al. 
(1982) indicated that the different levels of significant resistance to pyrethroids exhibited by the field strains are the result of cross-resistance with other groups of insecticides and not due to intensive or prolonged applications of these materials.

As for organophosphates, the cotton leafworm population in Menofia governorate exhibited moderate resistance levels. the highest level of tolerance was recorded to profenfos $(7.24$ fold) while chlorpyrifos exhibited (5.21 fold). In agreement to some extent to such performance, previous studies by several Egyptian investigators demonstrated that cotton leafworm field strains were highly resistance to methoxy (Chlorpyrifos-M) but not to ethyl (Chlorpyrifos-E) phosphates (EISayed and El-Guindy, 1975). Whereas, later on El-Guindy et al. (1978) showed that chlorpyrifos-ethyl which is halogenated ethoxy phosphate, began to lose its potency as indicated by the significant levels of resistance detected in some governorates. Farthermore, later on Issa et al. (1984-1985) reported that chlorpyrifos lost its effectiveness against several field strain during 1980 season.

As for resistance spectrum to the tested carbamate pesticide (Methomyl), high remarkable tolerance was recorded (8.23 fold). it seem to be more resistance than organophosphates. In contrast Rashwan et al. (1991-1992) found that tested field strains exhibited high resistance levels to tested insecticides which were much higher for organophosphates than for carbamates. The tolerance ratios of Menoufia strains of Spodoptera littoralis to insect growth regulators and naturally derived compounds after $48 \mathrm{~h}$. resulted in increase in susceptibility of IGR'S and naturally derived compounds recording tolerance ratios of $5.03,5.64,6.57,6.61$ and $\mathbf{1 0 . 0 9}$ fold for Methoxyfenozide,
Spinetoram, Indoxacarb, Hexaflumuron, Pyridayl and Flufenoxuron, respectively .

Generally, the obtained data concerning the onset of resistance or tolerance in Spodoptera littoralis field population to the newly developed insecticides belonging to Naturalyte class (Pyridayl, Spinetoram and Indoxacarb) partially agreed with the data recorded by several authors dealing with either lepidopterous insects or/and different insect species.

\section{2- Development of resistance : a-Resistance to Chlorpyrifos:}

The tolerance ratio data of Chlorpyrifos (Table 3) showed that Chlorpyrifos - selected strain exhibited tolerance ratios value within vigor tolerance times in the $1^{\text {st }}$ selected generation when exposed to $L C_{50}$ of Chlorpyrifos and the tolerance ratio increased and the strain being resistance within the following generations .

The estimated $\mathbf{L C}_{50}$ values were 15.36, 85.9, 96.24, 168.47, 224.89, 508.42 and $713.06 \mathrm{ppm}$ respectively, while the resistance ratios were $5.59,6.26,10.97$, $14.65,24.03,33.12$ and 46.45 fold, for the parent and Chlorpyrifos - treated generations from $1^{\text {st }}$ to $6^{\text {th }}$ respectively .

As shown in Table (3) the revealed that $\mathbf{L C}_{50}$ and tolerance ratio values exhibited slight and slow increase during the first three generations after selection with Chlorpyrifos ranging between 6.26 and 14.65 fold . However, at the $4^{\text {th }}$ generations, the $L_{50}$ values and resistance ratio increased, reaching $368.93 \mathrm{ppm}$ and 24.03 fold. And the same trend was recorded at the $5^{\text {th }}$ and $6^{\text {th }}$ generations, the recorded valuesof $\mathbf{L C}_{50}$ were 508.42 and $713.06 \mathrm{ppm}$, where the tolerance ratios of the same generations were 33.12 and 46.45 fold respectively. Such increase was adopted indicate that there are a conservable and high resistance for Chlorpyrifos. 
M. A.A. Sayed-Ahme, et al.,

Table (3): $\mathrm{LC}_{50}$, Tolerance ratios, $95 \% \mathrm{CL}$ and slope of chlorpyrifos -selected $4^{\text {th }}$ instar larvae of S.littoralis.

\begin{tabular}{|c|c||c||c|c||}
\hline Generation & Slope \pm ES & $\begin{array}{c}\mathrm{LC}_{50} \\
(\mathrm{ppm})\end{array}$ & $95 \% \mathrm{CL}$ & T.R \\
\hline S- strain & $1.2541 \pm 0.4329$ & 15.35 & $97.40-20604.95$ & -- \\
F- strain & $2.072 \pm 0.753$ & 85.90 & $256.54-9447.02$ & 5.59 \\
F1 & $2.335 \pm 1.0749$ & 96.24 & $328.01-81602.41$ & 6.26 \\
F2 & $4.240 \pm 1.360$ & 168.47 & $281.84-2089.12$ & 10.97 \\
F3 & $4.933 \pm 1.773$ & 224.89 & $356.03-1578.33$ & 14.65 \\
F4 & $10.401 \pm 3.119$ & 368.93 & $465.20-778.40$ & 24.03 \\
F5 & $14.964 \pm 4.747$ & 508.42 & $594.90-884.13$ & 33.12 \\
F6 & $18.239 \pm 6.046$ & 713.06 & $808.92-1152.39$ & 46.45 \\
\hline
\end{tabular}

\section{b-Resistance to Spinetoram:}

The Spinetoram selected strains data are shown in Table (4). These data clearly showed that the $\mathrm{LC}_{50}$ values were slightly increased until $3^{\text {th }}$ generations, when compared with parent and susceptible strains.

Trans after, a remarkable increase was recorded until the end of the experiment (6 generations). The $\mathrm{LC}_{50}$ values in the parent and the generations from $1^{\text {st }}$ to $6^{\text {th }}$ were 61.20, 82.72, 109.29, 163.96, 290.22, 426.2 and $606.46 \mathrm{ppm}$.

The tolerance ratios of different generations of Spinetoram selected strain (Table 4) followed the LC $_{50}$ value showing the same patterns of increase . This is normal as the tolerance ratios are compared from the LC50 values. The tolerance ratios were $2.16,2.96,3.92$, $5.88,10.41,15.29$ and 21.76 fold respectively. For the parent and selected generations from $1^{\text {st }}$ to $6^{\text {th }}$

Referring to data in Table (4), the development of resistance to Spinetoram in S.littoralis was characterized by an initial low rate ranging between 2.19 and 5.88 fold for a long period from parents to F3 generations. As for $4^{\text {th }}$ generations the level of resistance recorded 10.41 fold which represent the initial limit of vigor tolerance, then after the rate of development of resistance increased remarkably and reached $\mathbf{1 5 . 2 9}$ and 21.76 fold at the $5^{\text {th }}$ and $6^{\text {th }}$ selected generations. In general, the tolerance ratios indicated clearly that the Spinetoram selected strain was moderate tolerant until the $3^{\text {rd }}$ generation and become vigor tolerant until the $6^{\text {th }}$ generation.

The slope values of regression lines obtained from Spinetoram- selected strain were characterized by low slope values, where it was 1.283 for the parent, then decreased at the $1^{\text {st }}$ selected generation recording 0.882 and begin slight and gradual remarkable increase from the $2^{\text {nd }}$ generation (1.881) till the $6^{\text {th }}$ generation (13.591). Such performance of these generations typify those of 
populations beginning the development of true resistance where R.R reached considerable level of 15.29 and 21.76 fold within both $5^{\text {th }}$ and $6^{\text {th }}$ generations , respectively.

In agreement, laboratory studies carried out by several investigators against certain insect species, supported the possibility of development of resistance of Spinetoram through selection pressure by sublethal concentrations of the compound for certain successive generations. Rae et al., (2000) developed a highly Spinosad resistance strain of tobacco budworm (Heliothis virescens) in laboratory each generation topically and found that resistance was detected as early as the $6^{\text {th }}$ generation. In 14 generations, a concentration of $100 \mathrm{Mg} / \mathrm{larvae}$ produced $47.1 \%$ mortality and resistance ratios $\geq$ 763-fold based on a comparison of the $L D_{505}$. The parent strain demonstrated a similar susceptibility to Spinetoram. The susceptibility of the resistance strain did not revert back to that of susceptibility strain when reared six generations in the laboratory in the absence of Spinetoram. Selection, immigration of new genes and fitness challenges particular to the field environment. Likewise, Young et al., (2003) found that the selection of tobacco budworms each generation with topically applied technical Spinosad produced a laboratory strain which was highly resistance to the insecticide.

At the very last, our findings of resistance to Spinetoram and of selectable variation in susceptibility of Menoufia population showed serve as a warning of vulnerability of Spinetoram to resistance development in cotton leafworm . Efforts are urgently necessary by the producers of Spinetoram to restrict use of this product. Yet, it is only by careful monitoring of susceptibility that will be able to determine if the current limitations are sufficient to avert resistance under the intensive agricultural production conditions of Egypt .

Table (4): $\mathrm{LC}_{50}$ Tolerance Ratio, $95 \% \mathrm{CL}$ and slope of Spinetoram -selected $4^{\text {th }}$ instar larvae of S.littoralis

\begin{tabular}{|c||c||c||c||c|}
\hline Generation & Slope \pm ES & $\begin{array}{c}\text { LC } \\
(\mathrm{ppm})\end{array}$ & $95 \% \mathrm{CL}$ & T.R \\
\hline S- strain & $1.785 \pm 0.538$ & 27.87 & $86.02-1629.21$ & -- \\
F- strain & $1.283 \pm 0.433$ & 61.20 & $377.93-57643.49$ & 2.19 \\
F1 & $0.882 \pm 0.308$ & 82.72 & $1078.36-26561.91$ & 2.96 \\
F2 & $1.881 \pm 0.657$ & 109.29 & $361.46-16133.65$ & 3.92 \\
F3 & $3.764 \pm 1.337$ & 163.96 & $301.03-1998.50$ & 5.88 \\
F4 & $6.879 \pm 2.396$ & 290.22 & $397.13-888.33$ & 10.41 \\
F5 & $9.507 \pm 3.578$ & 426.20 & $540.01-1248.82$ & 15.29 \\
F6 & $13.591 \pm 5.118$ & 606.46 & $715.62-1287.26$ & 21.76 \\
\hline
\end{tabular}

* Tolerance Ratio (T.R) $=\frac{\text { LC }_{50} \text { of field strain }}{\text { LC }_{50} \text { of susceptible strain }}$ 


\section{REFERENCES}

Abbott, W.S. (1925). A method of comparing effectives of an insecticide. J. Econ. Entomol. 18: 265-267.

El-Bermawy, Z.A., A.A. El-Shiekh, M.H. Rashwan and H.S.A. Raswan (1991). Pyrethroids resistance in Spodoptera littoralis (Boisd.) (Lepidoptera: Noctuidae) in Lower Egypt. Bull. Ent. Soc. Egypt. Econ. Ser., 19:41.

El-Defrawi, M.E., A. Toppazada, N. Mansour and M. Zeid (1964). Toxicological studies on the Egyptian cotton cotton leaf worm prodenia litura(F). 1.Susceptibility of different larvae instars of prodenia to insecticides. J. Econ. Entomol., 57:591-593.

El-Guindy, M.A., S.M. Madi, M.E. Keddis, Y.A. Issa and M. Abdel- Satter (1982). Development of resistance to pyrethroids in field population of Egyptian cotton leafworm Spodoptera littoralis (Boisd). Bull. Ent. Soc. Egypt, Econ. Ser., 14: 373-383 .

El-Guindy, M. A., S. M. Madi, G. N. ElSayed, A. M. I. Farrag, S. M. A. Dogheim; M. A. Kaddis and Y. H. Issa. (1978). Further studies on resistance spectrum and subgrouping of certain insecticides in field populations of Egyptian cotton leaf worm, Spodoptera littoralis (Boisd.) during the 1980 cotton season. Bull. Ent. Soc. Egypt, Econ. Ser., 11:243-258.

El-sayed, G.N. and M.A. El-Guindy (1975). Resistance spectrum and subgrouping field population of the Egyptian cotton leafworm Spodoptera littoralis (Boisd.). Bull. Ent. Soc. Egypt, Econ. Ser. 9: 147-153 .

Finney, D.J. (1971). Propit analysis, a statistical treatment of the sigmoid response curve. Cambridje Univ.,
Press, Combridge, London, U.K. pp 318.

Georghiou, G.P. (1983). Management of resistance in arthropods. pp 7669-792. In C.P Georghiou and T. satto (eds), Pest resistance to pesticides. Plenum, New York.

Issa, Y.H., M.E. Keddis, M.M. Abdel-sattar, F.A. Ayad and M.A. El-Guindy (19841985). Survey of resistance to pyrithroids in field strains of the cotton leafworm Spodoptera littoralis (Boisd.) late in cotton seasons 19801984 . Bull. Ent. Soc. Egypt. Econ. Ser. 14:405-411 .

Kinpling, E.F. (1950). Insecticides resistance flies and mosquitos. Soap, Sanitary Chem. 26: 87-88.

Rae, M.A., W.D. Bailey, H.P. Young, C.F. Wyss, P. Duqqer and D. Richter (2000). Characterization of Spinosad (Tracer $R)$ resistance in laboratory strain of the tobacco budworm and development of novel diagnostics for resistance monitoring in the field. Proceeding Beltwide Cotton Conferences, San Antonio, USA, 4-8. January, 2: 926-929 .

Rashwan, M.H., Z.A. El-Bermawy, A.E. ElShiekh and H.S.A. Radwan (1991). The onset of the organophosphate and carbamate resistance among lower Egypt population of the cotton leafworm Spodoptera littoralis (Boisd). Bull. Ent. Son. Egypt. Econ. Ser. 14 :1991-1992.

Young, H.P., W.D. Bailey and R.M. Roe (2003). Spinosad selection of a laboratory strain of the tobacco budworm, heliothis virescens (Lepidoptera: Noctuidae) and characterization of resistance. Crop protection, 22 (2): 265-273. 
دراسات تكسيكولوجية علي مقاومة دودة ورق القطن لبعض المبيدات الحديثة في محافظة المنوفية

محمود عبدالله عبدالعليم سيداحمد (1)، زينب عبدالغني البرماوي(1)، طارق عفيفي الثيخ(2)

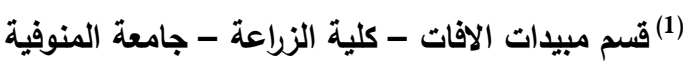

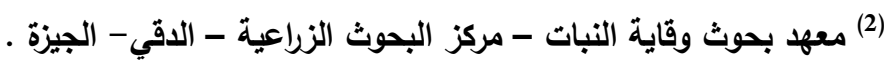

الملخص العربي

تعتبر دودة ورق القطن من أهم الآفات الحشرية التي تصيب العديد من محاصيل الحقل فضلا عن المحاصيل

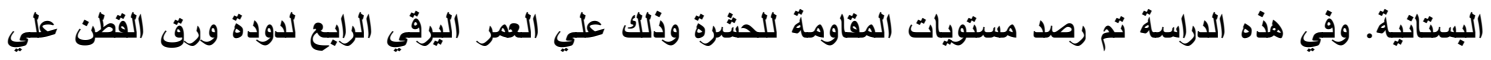
مدي موسمين متعاقبين (2016،2017) تجاه أحد عثر مبيدا" تمثل المجاميع الرئيسية للمبيدات (الفسفورية-

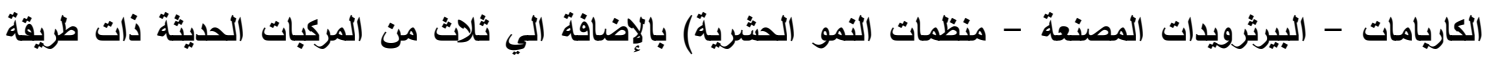
الفعل مختلف. وقد أظهرت الدراسة وجود درجة تحمل للسلالة لجميع المركبات المختبرة وذلك عند مقارنتها بالسلالة الحساسة .

وقد تم دراسة تطور درجة المقاومة لمركبين من المركبات المختبرة وهما مركب كلويبريفوس واسبينيتورام وذلك لمدة ستة أجيال متتالية حيث أوضحت النتائج زيادة كبيرة في مستوي المقاومة وصلت الي 46 ضعفا" لمركب الكلوربيريفوس درام وأما بالنسبة لمركب سبيتورام فقد وصلت درجة المقاومة بعد ستة أجيال منتخبة الي 21.76 ضعفا. 
M. A.A. Sayed-Ahme, et al.,

أ.د / محمـود حسـان رشـوان كلية الزراعة - جامعة المنوفية 
Menoufia J. Plant Prot., Vol. 4 April (2019): 45 - 53 